\title{
The Application Of Cartoon Puppet To Increase The Fairytale Learning Outcomes Of Elementary School Students.
}

\author{
Azizah Himawati \\ Universitas Sebelas Maret \\ azizahhimawati95@gmail.com
}

\section{Article History}

received 30/4/2021

\begin{abstract}
This research was motivated by the learning outcomes of fairytale of Indonesian language content that were still low in SD Negeri Sidomukti. This research aim was to improve the fairytale learning outcomes by using cartoon puppet. The type of the research was classroom action research. Data collecting technique used in this research were observation and learning outcomes test. The results showed that in the learning process, students became more active and the completeness of students learning outcomes increased in each cycle. Completeness of students learning outcomes which was initially $37 \%$ in precycle increased to be $63 \%$ in cycle I. That completeness of students learning outcomes increased to be $89 \%$ in cycle II of all students. The conclusion of this research was the application of cartoon puppet media can increase the students learning outcomes of garde II of SDN Sidomukti at the academic year 2020 / 2021.
\end{abstract}

Keywords: Cartoon puppet, learning outcomes, fairytale

\begin{abstract}
Abstrak
Penelitian ini dilatarbelakangi oleh hasil belajar Bahasa Indonesia materi dongeng pada peserta didik kelas II yang masih rendah di SD Negeri Sidomukti. Tujuan penelitian ini adalah untuk meningkatkan hasil belajar materi dongeng dengan menggunakan media wayang kartun. Jenis penelitian ini yaitu Penelitian Tindakan Kelas (PTK). Teknis pengumpulan data yaitu observasi dan tes hasil belajar. Hasil penelitian menunjukkan bahwa dalam proses belajar, peserta didik menjadi lebih aktif sedangkan ketuntasan peserta didik meningkat pada setiap siklusnya. Ketuntasan hasil belajar peserta didik yang mulanya $37 \%$ pada prasiklus meningkat pada siklus I menjadl $63 \%$. Ketuntasan tersebut meningkat lagi pada siklus II menjadi $89 \%$ dari keseluruhan peserta didik. Simpulan dari penelitian ini adalah penggunaan media wayang kartun dapat meningkatkan hasil belajar peserta didik kelas II SDN Sidomukti tahun pelajaran 2020/2021.
\end{abstract}

Kata kunci: Wayang kartun, hasil belajar, dongeng 


\section{PENDAHULUAN}

Pendidikan merupakan suatu usaha untuk membangun kehidupan masyarakat di masa kini dan masa depan guna memperoleh kehidupan yang lebih baik. UndangUndang Sistem Pendidikan Nasional Nomor 20 Tahun 2003 menerangkan bahwa pendidikan berfungsi untuk mengembangkan potensi dan membentuk watak sehingga menjadi bangsa yang bermartabat.

Pembelajaran Bahasa Indonesia merupakan mata pelajaran yang dibelajarkan di semua jenjang pendidikan termasuk di Sekolah Dasar. Pembelajaran Bahasa Indonesia memiliki peranan penting sebagaimana tertera dalam Permendiknas No 22 Tahun 2006 tentang Standar Isi, bahasa memiliki peran sentral dalam perkembangan intelektual, sosial, dan emosional peserta didik serta merupakan penunjang keberhasilan dalam mempelajari semua bidang studi. Hal tersebut menunjukkan bahwa pembelajaran bahasa harus dilaksanakan dengan sungguhsungguh karena perannya yang begitu penting bagi kemajuan peserta didik.

Salah satu kajian pembelajaran Bahasa Indonesia adalah sastra. Anak perlu mendapatkan pengetahuan sejak awal agar kelak dapat memiliki wawasan global. Sastra bercerita tentang kehidupan yang mampu menjadikan manusia seutuhnya. Sastra anak merupakan sastra yang ditujukan kepada anak-anak agar anak mendapatkan banyak manfaat dan berguna bagi kehidupan di masa yang akan datang. Sastra anak memiliki manfaat terhadap pihak anak untuk perkembangan intelektual dan perkembangan emosional. Sastra anak dapat bermanfaat untuk perkembangan karakter anak.

Salah satu genre sastra anak adalah dongeng. Dongeng merupakan media yang sangat efektif untuk menanamkan berbagai nilai dan etika terhadap anak, termasuk menimbulkan rasa empati dan simpati anak. Nilai-nilai yang bisa dipetik dari dongeng adalah nilai kejujuran, kerendahhatian, kesetiakawanan, kerja keras, dan lain sebagainya.

Kegiatan bercerita atau dongeng sangat penting bagi anak. Kurniawan (2013) menyatakan bahwa jika anak terbiasa mendengar dongeng, anak akan semakin cepat belajar karena mereka telah kaya akan kosakata. Oleh karena itu, sudah seharusnya pembelajaran dongeng dilaksanakan dengan konsep yang menarik agar peserta didik tertarik dengan dongeng. Dalam hal ini, guru memiliki peran penting dalam mengarahkan peserta didik sesuai bakat dan keterampilan yang mereka miliki (Sabillah, 2012).

Berdasar hasil pengamatan kegiatan pembelajaran muatan pelajaran Bahasa Indonesia pada tanggal 27 Februari 2021 pada kelas II SDN Sidomukti, diketahui bahwa metode pembelajaran yang digunakan dalam pembelajaran Bahasa Indonesia di masa pembelajaran daring masih didominasi penugasan melalui grup WA. Penugasan materi Bahasa Indonesia yang dimaksud adalah siswa membaca materi secara individu, kemudian mengerjakan Lembar Kerja Peserta Didik secara mandiri. Penugasan membaca teks Bahasa Indonesia yang cenderung panjang secara mandiri merupakan hal yang membosankan bagi peserta didik. Selain itu, media pembelajaran yang digunakan kurang variatif.

Berdasarkan hasil tes pratindakan materi dongeng pada tanggal 1 Maret 2021, dapat diketahui bahwa pemahaman peserta didik terhadap materi dongeng masih rendah. Dengan nilai Kriteria Ketuntasan Minimal (KKM) untuk muatan pelajaran Bahasa Indonesia 75, nilai uji pra tindakan menunjukkan bahwa dari 19 peserta didik hanya ada 7 peserta didik (37\%) yang nilainnya lebih dari atau sama dengan KKM. Sejumlah 12 siswa (63\%) nilainya masih di bawah KKM. Saat pembelajaran materi dongeng, sebagian besar peserta didik kesulitan memahami isi dongeng.

Dari hasil observasi dan tes pratindakan, dapat ditarik kesimpulan bahwa sebagian besar peserta didik masih kesulitan dalam memahami isi dongeng. Selain itu, pembelajaran Bahasa Indonesia yang didominasi penugasan melalui grup WA serta 
penggunaan media pembelajaran yang kurang variatif mengakibatkan rendahnya hasil belajar Bahasa Indonesia kelas II SDN Sidomukti.

Kenyataan di atas merupakan permasalahan yang harus segera dipikirkan pemecahannya agar hasil belajar materi dongeng peserta didik meningkat. Untuk meningkatkan hasil belajar peserta didik dalam materi dongeng, diperlukan media pembelajaran yang relevan yang mampu memvisualisasikan konsep yang ingin disampaikan kepada peserta didik. Media pembelajaran tersebut diharapkan dapat membantu peserta didik dalam menggali informasi dari suatu dongeng, mengaktifkan peserta didik saat mengikuti pembelajaran, dan menciptakan suasana yang menyenangkan serta bermakna bagi peserta didik.

Arsyad (2011:3), mengatakan media adalah suatu alat yang dipakai sebagai saluran untuk menyampaikan pesan atau informasi kepada penerimanya. Media merupakan alat bantu pembelajaran yang digunakan untuk memudahkan guru dalam menyampaikan materi yang akan disampikan pada peserta didik saat pembelajaran. Penggunaan media dalam pembelajaran menurut Hamalik (Arsyad, 2011:15-16) dapat membangkitkan minat, motivasi, rangsangan kegiatan belajar, dan membawa pengaruh psikologis bagi peserta didik. Penggunaan media pembelajaran akan membantu keefektifan pembelajaran dan penyampaian pesan atau isi pelajaran. Penggunaan media dalam pembelajaran penting dilakukan, selain membangkitkan motivasi dan minat peserta didik dalam belajar, penggunaan media pembelajaran juga dapat membantu meningkatkan pemahaman siswa akan materi pelajaran, dan memudahkan guru dalam menyampaikan pelajaran.

Di sini peneliti telah menganalisis beberapa media pembelajaran yang sesuai dan relevan dengan bidang kajian pembelajaran bahasa Indonesia materi dongeng yaitu menggunakan media pembelajaran kreatif media wayang kartun. Banyaknya media belajar yang digunakan, kesenian wayang merupakan salah satu media yang efektif dalam menyampaikan pesan pembelajaran. Bukan hanya sebagai hiburan belaka namun dengan kesenian wayang, unsur-unsur pendidikan dalam bermasyarakat juga dapat tersampaikan (Haryono, 2013:140). Wayang kartun terdiri atas suatu bentuk potongan kertas yang diikatkan pada sebuah batang (Sudjana dan Rivai 2010:190). Kesederhanaan dari pembuatan dan permainannya menyebabkan wayang mudah diadaptasikan dalam penggunaannya di tingkat pertama pada sekolah dasar. Wayang kartun banyak digunakan sebagai media pendidikan. Hal ini disebabkan banyak pesan yang dapat dimasukkan dalam kegiatan ini.

Salah satu media pembelajaran yang mampu mengaktifkan peserta didik dalam pembelajaran dongeng adalah wayang kartun. Wayang kartun adalah suatu benda tiruan dari bentuk manusia atau binatang yang terbuat dari kertas, kardus, kulit, atau seng dan berpenampilan lucu. Kelebihan wayang kartun yaitu mudah dibuat, melibatkan panca indera peserta didik dalam kegiatan bercerita, dapat menarik siswa, memudahkan peserta didik menyampaikan isi dongeng yang telah dipahami, penggambaran tokoh abstrak menjadi nyata, dapat digunakan dalam kegiatan yang sifatnya berkelompok atau klasikal, serta menumbuhkan percaya diri peserta didik.

Rumusan masalah dari penelitian tindakan kelas ini adalah: Apakah penggunaan media wayang kartun dapat meningkatkan hasil belajar Bahasa Indonesia materi dongeng peserta didik kelas II SDN Sidomukti Tahun Ajaran 2020 / 2021?

Berdasarkan rumusan masalah, maka tujuan penelitian ini yaitu: Untuk meningkatkan hasil belajar Bahasa Indonesia materi dongeng peserta didik kelas II SDN Sidomukti Tahun Ajaran 2020 / 2021.

\section{METODE}

Penelitian ini merupakan pendekatan penelitian kualitatif. Jenis penelitian yang digunakan dalam penelitian ini merupakan jenis Penelitian Tindakan Kelas (PTK) atau Classroom Action Research dengan model siklus yang memiliki empat tahap yaitu 
perencaan, pelaksanaan, pengamatan, dan refleksi. Penelitian ini dilaksanakan pada semester genap tahun ajaran 2020/2021 selama empat bulan yaitu mulai bulan Februari 2021 sampai bulan Juni 2021

Subjek penelitian ini adalah guru dan 19 peserta didik SD Negeri Sidomukti dengan 10 peserta didik laki-laki dan 9 peserta didik perempuan. Teknik analisis data yang digunakan dalam penelitian ini adalah teknik analisis interaktif yang terdiri dari tiga komponen yaitu reduksi data, penyajian data, dan penarikan kesimpulan/verifikasi. Alat pengumpulan data dalam penelitian ini berupa observasi dan tes hasil belajar. Validitas data yang digunakan dalam penelitian ini adalah triangulasi sumber dan triangulasi teknik.

\section{HASIL DAN PEMBAHASAN}

Penggunaan media wayang kartun untuk meningkatkan hasil belajar Bahasa Indonesia materi dongeng dilaksanakan selama dua siklus. Masing-masing siklus terdiri atas 2 pertemuan. Setiap pertemuan dilakukan secara sinkronus melalui platform Zoom Meeting. Langkah pertama peserta didik menjawab pertanyaan pemantik yang diberikan oleh guru. Kemudian, peserta didik menyimak guru yang sedang membawakan dongeng melalui pttaform zoom. Peserta didik mendapat instruksi dari guru untuk mengerjakan LKPD (Lembar Kerja Peserta Didik) mengenai dongeng yang telah dibawakan oleh guru. Kemudian, guru memberikan penguatan tentang materi dongeng. Peserta didik diberi kesempatan untuk bertanya apabila ada materi yang belum dipahami. Guru memberikan apresiasi kepada peserta didik.

Berdasarkan hasil penelitian, hasil observasi guru dan peserta didik serta hasil belajar Bahasa Indonesia materi dongeng mengalami peningkatan di setiap siklusnya. Penggunaan media wayang kartun tidak hanya berdampak pada meningkatnya hasil belajar materi dongeng, melainkan juga berdampak pada peningkatan kinerja guru serta aktivitas peserta didik. Peningkatan tersebut dapat dilihat dari pencapaian nilai rata-rata dan persentase ketuntasan pada siklus I, dan siklus II.

Tabel 1. Perbandingan Hasil Observasi Guru dan Peserta Didik tiap Siklus

\begin{tabular}{cccc}
\hline No & Siklus & $\begin{array}{c}\text { Observasi } \\
\text { Guru }\end{array}$ & $\begin{array}{c}\text { Observasi } \\
\text { Peserta Didik }\end{array}$ \\
\hline 1 & Siklus I & 63,2 & 59,25 \\
2 & Siklus II & 84,5 & 74,5 \\
\hline
\end{tabular}

Berdasarkan tabel 1, terjadi peningkatan skor kinerja guru dari 63,2 menjadi 84,5. Peningkatan tersebut terjadi karena guru telah memberbaiki kekurangan siklus I pada siklus II. Pada siklus I, guru masih kurang mengoptimalkan pembuatan tokohtokoh wayang kartun sehingga saat mendongeng, tokoh yang ditampilkan sangat terbatas. Guru hanya membuat wayang tokoh utama, sementara tokoh-tokoh tambahan dan penggambaran latar suasana tidak diwujudkan dalam bentuk wayang kartun. Selain itu, pengisian suara tokoh wayang kartun cenderung monoton antara tokoh yang satu dengan tokoh yang lain. Peserta didik sebagian masih pasif karena guru belum melibatkan mereka secara optimal dalam memainkan media wayang kartun. Pada siklus II, guru telah membawakan tokoh-tokoh baik uutama maupun penunjang dengan baik. Guru mampu mengisi suara tokoh-tokoh secara heterogen sehingga memudahkan peserta didik untuk memahami isi dongeng. Selain itu, peserta didik telah dilibatkan secara aktif saat guru mendongeng dengan cara kegiatan tanya jawab.

Hasil observasi peserta didik menunjukkan peningkatan dari siklus I ke siklus II. Pada siklus I, peserta didik mendapat skor 59,25 dan meningkat pada siklus II menjadi 74,5 . Pada siklus I sebagian besar peserta didik masih malu untuk berbicara dan 
menyampaikan pendapatnya. Mereka baru akan menjawab pertanyaan dari guru apabila ditunjuk oleh guru. Selain itu, beberapa peserta didik masih terlihat acuh terhadap kegiatan pembelajaran dan lebih memlilih diam sepanjang kegiatan sinkronus melalui zoom berlangsung. Pada siklus II antusiasme dan rasa percaya diri peserta didik sudah baik. Suasana pembelajaran semakin menyenangkan sehingga peserta didik terlibat aktif dalam kegiatan mendengar, berbicara, membaca, menulis, dan juga aktif secara mental. Guru pada siklus II lebih banyak memberikan penguatan positif dan reward secara verbal kepada peserta didik yang aktif terlibat dalam kegiatan tanya jawab dan diskusi. Selain itu, guru lebih banyak memberikan motivasi kepada peserta didik yang cenderung pasif saat kegiatan berlangsung.

Data hasil belajar peserta didik diperoleh dari hasil evaluasi setelah kegiatan pembelajaran siklus I dan II. Hasil belajar peserta didik dapat dilihat pada tabel 2 berikut.

Tabel 2. Perbandingan Hasil Belajar Peserta Didik Siklus I dan Siklus II

\begin{tabular}{clcc} 
No & \multicolumn{1}{c}{ Keterangan } & Siklus I & Siklus II \\
\hline 1. & Nilai terendah & 50 & 65 \\
2. & Nilai tertinggi & 90 & 95 \\
3. & Nilai rata-rata & 74,7 & 81,1 \\
4. & Ketuntasan klasikal (\%) & $63 \%$ & $89 \%$ \\
\hline
\end{tabular}

Dari tabel 2 di atas, terlihat bahwa hasil belajar peserta didik meningkat dari siklus I ke siklus II. Ketuntasan klasikal pada siklus I yaitu $63 \%$ dengan nilai rata-rata 74,7 dan meningkat pada siklus II menjadi $89 \%$ dengan nilai rata-rata 81,1 . Ketuntasan hasil belajar pada siklus II telah mencapai indikator kinerja penelitian yang telah ditentukan (85\%). Pada siklus I, peserta didik masih kesulitan saat menjawab soal tes berkaitan isi dongeng yang berbasis HOTS. Selain itu, mereka masih kesulitan dalam menuangkan jawaban dalam wujud kalimat tertulis dengan bahasa mereka sendiri. Pada siklus II, guru memperbaiki proses pembelajaran dengan membawakan dongeng menggunakan bahasa yang lebih sederhana dan mudah untuk dimengerti peserta didik. Hasil tes pada siklus II meningkat dari siklus I terlihat dari semakin banyak peserta didik yang mempu menjawab pertanyaan berbasis HOTS dengan kalimat mereka sendiri. Berdasarkan hasil evaluasi, disimpulkan bahwa terjadi peningkatan hasil belajar Bahasa Indonesia materi dongeng pada peserta didik kelas II SDN Sidomukti. Ketercapaian indikator $89 \%$ disebabkan karena penggunaan wayang kartun yang telah diperbaiki dan ditambah inovasi untuk menutupi kelemahan-kelemahan media tersebut.

Data yang diperoleh peneliti menunjukkan bahwa hasil belajar mengalami peningkatan. Hal tersebut juga dapat dilihat pada penelitian yang dilakukan Lestari (2016) yang membuktikan bahwa penerapan media wayang kartun dapat meningkatkan keterampilan menyimak cerita pada peserta didik kelas V SD Negeri 149 Palembang. Peningkatan keterampilan menyimak cerita anak diketahui dengan hasil tes keterampilan menyimak cerita anak yang dilaksanakan pada setiap siklus. Hasil tes menunjukkan peningkatan ketuntasan nilai peserta didik pada siklus I sebesar $54,29 \%$, siklus II sebesar $68,57 \%$, dan siklus III sebesar $88,57 \%$.

Berdasarkan pembahasan hasil di atas tentang hasil belajar peserta didik yang didukung dengan penelitian yang telah dilakukan, dapat disimpulkan bahwa media wayang kartun dapat meningkatkan hasil belajar Bahasa Indonesia materi dongeng pada peserta didik kelas II SDN Sidomukti tahun ajaran 2020 / 2021.

Dalam pembelajaran yang dilakukan selama sikllus I dan II terdapat kendala yang kerap muncul yaitu sebagian peserta didik cenderung pasif saat guru sedang 
mendongeng melalui Zoom Meeting. Solusinya yaitu guru harus lebih aktif melibatkan peserta didik secara langsung saat kegiatan mendongeng menggunakan wayang kartun dengan cara interaksi dua arah sebagaimana yang dikatakan Fauzi (2014) bahwa salah satu kelebihan wayang kartun yaitu membuat peserta didik menjadi percaya diri dan aktif.

Kendala lain yang dihadapi yaitu jumlah wayang yang terbatas karena tokoh dalam dongeng yang terbatas juga. Selain itu guru harus membuat bentuk wayang yang menarik agar peserta didik tidak bosan. Hal tersebut sejalan dengan pendapat Fauzi (2014) bahwa kekurangan wayang kartun yaitu menuntut guru untuk menciptakan bentuk-bentuk wayang yang lebih kreatif. Solusi yang guru lakukan adalah membuat wayang kartun dengan inovasi yang lebih kreatif dan menarik sebagaimana Aqib (2013) mengatakan bahwa prinsip umum pembuatan media pembelajaran yaitu menarik.

\section{SIMPULAN}

Berdasarkan hasil penelitian yang sudah dibahas pada bab sebelumnya dapat disimpulkan bahwa penggunaan media wayang kartun dapat meningkatkan hasil belajar Bahasa Indonesia materi dongeng pada peserta didik kelas II SD Negeri Sidomukti tahun pelajaran 2020/2021. Ketercapaian persentase ketuntasan klasikal nilai hasil belajar Bahasa Indonesia materi dongeng yaitu $37 \%$ dengan nilai rata-rata 69 , meningkat pada siklus I menjadi $63 \%$ dengan nilai rata-rata 74,7 , meningkat pada siklus II menjadi $89 \%$ dengan nilai rata-rata 81,1 .

Kendala yang ditemui selama penelitian yaitu peserta didik cenderung pasif saat kegiatan pembelajaran dongeng berlangsung, kesulitan menjawab soal HOTS, dan masih malu-malu saat menjawab pertanyaan dari guru. Selain itu, kendala yang ditemui guru adalah kesulitan dalam membuat bentuk wayang yang menarik minat peserta didik. Solusi yang guru lakukan adalah memberikan motivas dan penguatan positif kepada peserta didik, menciptakan bentuk wayang yang beraneka dan lebih kreatif, serta menyampaikan dongeng menggunakan bahasa yang lebih sederhana dan mudah dimengerti peserta didik.

Hasil penelitian ini sangatlah penting untuk direkomendasikan kepada guru kelas maupun guru mata pelajaran untuk meningkatkan proses dan hasil belajar peserta didik di sekolah. Tindak lanjut yang dapat dilakukan oleh guru adalah mensosialisasikan penggunaan wayang kartun kepada guru kelas lain dalam kegiatan diklat, KKG, atau kegiatan pengembangan profesionalitas guru lainnya.

\section{DAFTAR PUSTAKA}

Aqib, Z. (2013). Model-model, Media, Strategi Pembelajaran Kontekstual (Inovatif). Bandung: Yrama Widya.

Arsyad, Azhar. (2011). Media Pembelajaran. Jakarta: PT. Raja Grafindo Persada.

Fauzi, Miftah. (2014). Kupas Tuntas Secara Jelas Sampai Akar-akarnya Bahasa Indonesia SD Kelas 4, 5, dan 6. Jakarta: Pustaka Nusantara Indonesia

Haryono. (2013). Pembelajaran IPA yang Menarik dan Mengasyikkan: Teori dan Aplikasi PAIKEM. Purworejo: Kepelpress.

Kurniawan, Heru. (2013). Keajaiban Mendongeng. Jakarta: PT Bhuana Ilmu Populer.

Lestari, Sastri Dwi. (2016). Penerapan Media Wayang Kartun untuk Meningkatkan Keterampilan Menyimak Cerita Anak Siswa Kelas V SD Negeri 149 Palembang. Diakses dari https://ejournal.unsri.ac.id/index.php/jisd/article/view/8331

Permendiknas No 22 Tahun 2006 tentang Standar Isi

Sudjana, Nana dan Ahmad Rivai. (2010). Media Pengajaran. Bandung: Sinar Baru Algesindo.

Undang-Undang Sistem Pendidikan Nasional No. 20 Tahun 2003 